\title{
Strategic Readiness for CRM Process Management: the Case of Business Service Companies in Bulgaria
}

\author{
Dr. Evgeni Petrov Stanimirov \\ University of Economics-Varna \\ Dr. Vladimir Sashov Zhechev \\ University of Economics-Varna \\ Dr. Maria Radoslavova Stanimirova \\ University of Economics-Varna
}

\begin{abstract}
Customer Relationship Management (CRM) represents an iterative process aimed at improving interactions with customers and balancing companies' client portfolio. From the viewpoint of organizational measures taken, the key factors that influence the effectiveness of this process can be divided into: sharing of fundamental principles for managing customer relationships; accurate positioning of the particular CRM components; acknowledgment of the interdependencies between various stages of the CRM process. This allows identifying CRM components crucial to the management of the process of interaction with customers. The article explores the individual components of the CRM process, the latter being a premise on which adequate management of customer relationships is built. The paper proposes a methodology for assessment of the different components of the CRM process. It looks at the results from a study on the strategic readiness of companies, engaged in business services from four different sectors in Bulgaria, to manage their customer relationships. The empirical research is limited to investigation of the CRM vision and CRM base of the aforementioned companies. For the purposes of the study the researchers have collected and processed data in corporate areas as: management principles; practices for analysis and assessment of clients; corporate and organizational culture; customer databases management. The results serve as basis for inferences in the context of development of CRM practices for the business services sector.
\end{abstract}

Keywords: CRM process, CRM vision, CRM base, Business services.

\section{INTRODUCTION}

CRM has become a new paradigm of the modern marketing, main priority and an important tool for many companies which want to build long-term and profitable relationships with their customers (Kim et al. 2010). CRM is a logical process oriented towards balancing of the customer portfolio of the companies and in this sense it is related to their marketing results. Positive effects of the implementation of CRM are visible in many areas: consumer behavior (Barone 
et. al. 2000), better market performance and sustaining desired competitive position (Alsmadi \& Alnawas 2001), improvement of the financial results (Lamparello 2000), reduction of the mistakes made in customer service and increasing of the efficiency of the marketing campaigns (Gudkova 2005) etc.

Key factors which influence the efficiency of this process are: sharing of the fundamental principles of management of the relationships with customers; the correct positioning of the individual CMR components; acknowledgment of the interdependence between the individual phases of the CRM process. This allows the identification of CRM components which are of key importance for managing the process of interaction with customers.

However, the success of the CRM projects is not unconditional. Between $30 \%$ and $80 \%$ of them do not achieve the planned objectives (Kinikin 2000; Nelson 2002). The main reasons for their failure are: incorrect understanding of CRM as a technological solution (Johnson 2004), lack of strategic vision and plan (Day 2003), lack of the necessary skills for efficient management and integration of the CMR technologies in the sale process of companies (Erffmeyer, Johnson 2001) etc.

The said reasons for the disappointment of some companies by the launching of CRM projects show that the problems mainly consists of misunderstanding or false implementation of CMR as a concept and / or strategy. Therefore, from a practical point of view it is interesting to explore the practices of companies in the management of relationships with customers by monitoring the presence/absence and the use of key elements of the CRM strategy in this process.

Therefore, the goal of this article is to establish the strategic readiness of companies, specialized in offering marketing services to the B2B market in Bulgaria, to manage the CRM process. The strategic readiness for the management of the CRM process is a result of the providing of a specific vision and specific infrastructure (base) for the management of the relationships with the customers.

\section{METHODOLOGY}

As stated above, the success of the CRM projects depends on a Inquiry variety of factors, some of which are of key importance: the correct 2016/1 definition and positioning of the individual CRM components; the opportunity to identify the interdependence between the individual phases of the CRM process etc. For identification of the individual components of the CRM process the "CRM diamond", developed by Mack, Mayo \& Khare (2005) can be used. It consists of the following blocks: CRM vision, CRM base and CRM activities. The CRM model developed by Alsmadi \& Alnawas (2001) can be especially useful by the establishment of the interdependence between the individual phases of the CRM process. This model comprises a series of steps which the managers have to undertake for successful realization of CRM projects in their companies. 
The components of the model "CRM diamond" of Mack, Mayo \& Khare (2005), being dynamized by following the logic of the CRM model, developed by Alsmadi \& Alnawas (2001) CRM, are used as a starting point in this study. The combining of the said models is imperative given the holistic nature of the CRM concept. The model of Mack, Mayo \& Khare informs of the CRM components and in this sense it is descriptive in nature. On the other hand, the model offered by Alsmadi \& Alnawas shows the development (or phases) of the said components which makes it process-oriented. Both models discussed here are used as a base to offer an adapted model of the strategic CRM process (cycle) by the authors. The adaptation is needed for more correct classification of some CRM components to the different blocks (vision and base) which are subject to this study.

The study was conducted through planning of research instruments (a questionnaire) to collect primary information. The study covered subjects with economic activities in the territory of the Republic of Bulgaria regardless of their place of registration.

The questionnaire is structured in blocks (vision and base) representing consecutive stages of the strategic CRM cycle. All questions are evaluated using a standardized 5-point scale (from 1 "the statement does not describe our environment at all" to 5 - "the statement fully describes our environment"). The unified approach to assessment at all stages of the strategic process aims to provide conditions for direct comparisons between the individual CRM components. The assessment scales are tested for reliability using the Cronbach's Alpha criterion.

The assessment of the CRM vision is formed based on the following statement: „The company has a clear vision for its customers which allows it to effectively manage the relationships with them". The CRM vision is represented by two components in the following blocks:

Block "Guiding principles". The generalizing variable for the assessment of the guiding principles is as follows: „Managers are convinced that systematic management of customer relationships increases the profitability of the company". This block is operationalized through 4 statements: „The company has specific objectives in managing customer relationships“, „The company has a clear strategy for managing relationships with customer", "It is known in the company that the customers have different statuses (strategic, important, insignificant and unprofitable customers) “ and „The company treats its customers differently depending on their status (strategic, important, insignificant and unprofitable customers)“.

Block "Analysis and assessment of clients". The generalizing variable for this block is: „The company realizes that it is necessary to continuously analyze and assess its customers". 4 operationalization variables are provided as follows: „The company realizes that analysis is a prerequisite for recognition of prospective customers“, „The company 
realizes that the analysis and assessment of customers is a prerequisite for the differentiation between important and insignificant customers", "The company realizes that the analysis and assessment of customers is a prerequisite for efficient interaction with them", "The company realizes that the analysis and assessment of customers is a prerequisite for making offers which are tailored to individual customer demands".

The assessment of CRM base is formed based on the following statement: „The necessary conditions for efficient management of the relationships with customers have been created in the company". Within this stage 4 CRM components are provided in the following blocks:

Block „Customer-oriented corporate culture“. For the objectives of the study the following generalizing variable is used: „The staff at all levels within the company believes that customers are main factor for the business development". The operationalization variables within this block are 4: "The company organizes training for work with customers", "The staff which communicates with customers is informed about the goals of the company", „The staff which communicates with customers is familiar with the strategy of the company" and "The company has clear procedures (standards) for the fulfillment of the customeroriented activities (e.g. offering, service, handling of complaints)“.

Block "Organizational structure". The variable used for the assessment of the organizational structure is: "The organizational structure of the company allows efficient management of the relationships with customers". The operationalizing variables hereof are as follows: „The company has a department or specialist/s/ in charge whose task is to research the customers" and "The company has a department or specialist/s/ in charge whose task is to develop offers for different customers".

Block "Customer research activities“. For the assessment of the customer research practices the following generalizing variable is used: „The company systematically researches its customers". This block stands out due to the highest number of operationalizing variables whose objective is to cover various nuances of the said activity in the studied companies: "The company observes the satisfaction of its customers", "The company observes the loyalty of its customers", "The company assesses the customers based on the volume of their purchases", "The company assesses the customers based on their individual contribution to the profit", "The company assesses the customers based on the purchase frequency", "The company assesses the customers based on their propensity to give it market information", „The company assesses the customers based on of their propensity to give ideas for the improvement of the offer".

Block „Database management". The generalizing variable for this block is: „The company analyses and classifies information which helps it to manage the relationships with customers". This block 
consists of 3 operationalizing variables: „The company maintains data bases with personal information about individual customers", „The company maintains data bases with information about the behavior of the customers (purchase frequency, purchase volume, number of claims etc.) ", „The company has software which helps it to analyze the customers and prepare offers".

The specifications here above allow the presentation of the operational model of the study (Figure 1).

Figure 1: Operational model of the study

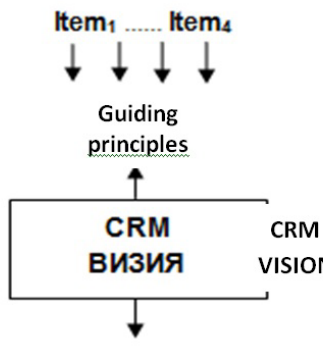

Analysis and assessment of the customers

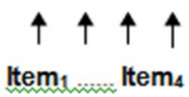

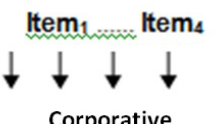

Corporative
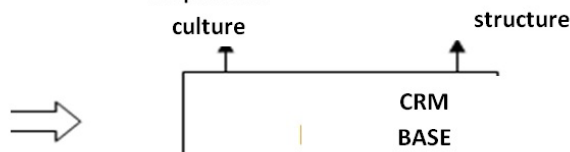

Objects of the study are managers of companies specializing in 4 types of business services: accounting, financial, marketing and legal services in the territory of the Republic of Bulgaria. The choice of respondents on a senior management level arises because of the fact that they define or are familiar with the objectives and the strategic intents of the companies they manage. The number of the respondents according to the specialization of the companies they manage is as follows: accounting services - 141; financial services - 115; marketing services - 104 and legal services - 120. The said number includes the managers who have taken part in the survey whereas it must be taken into consideration that within one company more than one questionnaire can be filled in. The sample is of "convenience" type.

\section{RESULTS}

The data about the values of the Cronbach's Alpha criterion show that all of the assessed constructs are of an acceptable and high level of reliability (the coefficient varies between 0,613 and 0,897).

In order to study the CRM practices according to branches an analysis of the presented variables in the operational model (figure 1) has been conducted. The analysis is based on: one-dimensional distribution, calculated average estimate, standard deviations and coefficients of variation.

\section{3}


The first stage of the strategic cycle of the customer relationships management is the CRM vision (table 1 ).

Table 1: Evaluation of the CRM vision according to branches

\begin{tabular}{|l|c|c|c|c|}
\hline \multirow{2}{*}{ Indicators } & \multicolumn{4}{|c|}{ Type of services rendered } \\
\cline { 2 - 5 } & Accounting & Financial & Marketing & Legal \\
\hline Arithmetic mean & 4,43 & 4,64 & 4,58 & 4,15 \\
\hline Standard deviation & 0,70 & 0,71 & 0,66 & 1,21 \\
\hline $\begin{array}{l}\text { Coefficient of } \\
\text { variation }\end{array}$ & 0,16 & 0,15 & 0,14 & 0,29 \\
\hline
\end{tabular}

The data in Table 1 show that the mean scores for the CRM vision are located in the positive side of the scale only. The highest mean scores are observed for companies specializing in financial and marketing services where $94 \%$ of the respondents state that they have a clear vision for their customers, which allows them to efficiently manage the relationships with them. The highest standard deviation is established for law firms where about $25 \%$ do not agree on the existence of a clear vision for management of relationships with customer. Regardless of the higher value of the standard deviation hereof, the variation does not reach the critical level of $50 \%$ in any of the branches, which means that the variance is within acceptable limits.

The components "Guiding principles for the management of the relationships" and "Analysis and assessment of the customers" are assessed within the framework of the CRM vision.

The guiding principles for the management of the relationships with customers are operationalized through 5 variables (Table 2). High mean scores are formed under the first three indicators within this block. The respondents believe that the systematic management of the relationships with customers increases the profitability of the company. The relative quota of the representatives of accounting, financial and marketing companies which partially or fully share this opinion lies between $94 \%$ and $98 \%$. Only with law firms, where this question also forms a positive score $(4,16)$, the quota of the respondents which have answered positively, is about $70 \%$.

Scores with low variance are formed which show that the companies have specific goals for management of the relationships and undertake concrete measures in this area. Results of this kind are somewhat surprising, as their comparison to the other two statements within the studied block ("Guiding principles") shows some inconsistencies. The discrepancies in the answers are most expressed for the companies offering accounting services. On the one hand they state that the relationships should be managed and that there are clear goals and strategies according to the customers, but on the other hand the idea that the customers have different status (strategic, important, 
insignificant, etc.) is not accepted. A significant part of the managers (between $30 \%$ and $43 \%$ according to branches) do not believe that customers are treated or should be treated differently according to their status.

The status of the customers and the resultant personalized strategies for different customers are basic concepts for the marketing of the relationships, the personalized marketing and CRM. The data shows that there is a problem in the practical acceptance of this principal idea. On one hand it is acknowledged that relationships should be managed, on the other hand this statement is not realizable if the customer data base is not differentiated and used for purposeful interaction.

The second aspect of the CRM vision is the analysis and evaluation of customers (Table 2). Two branches (finance and marketing) stand out, as distinctly higher scores compared to the accounting and law firms are formed here. As a whole a significant quota of the managers in the four studied business branches (between $85 \%$ and $91 \%$ in the area of accounting, financial and marketing services and $66 \%$ in the areas of the legal services) believe that it is necessary to systematically analyze and assess the customers and based on this to identify the prospective customers. An interesting decline of the magnitude of the mean scores is observed for the statement that the analysis and the assessment of the customers are a prerequisite for the differentiation between important and insignificant customers. A possible reason for this is that in reality in a large part of the companies no special analyses of customers are conducted (especially in companies which are small and do not have CRM software) and the importance of the customers is determined intuitively or based on metrics as: customer's share in the sales, contribution of the customer through positive information sharing and attracting new customers, providing of important market information etc.

The managers who took part in the study (65\% of the respondents in the legal branch and between $85 \%$ and $90 \%$ in the other business branches) understand that the analysis and assessment of the customers are a precondition for efficient interaction with them. An interesting overlapping of the answers is observed between the last two statements. Their comparison can lead to the conclusion that according to the respondents the efficiency of the interaction is determined by the ability of the companies to make offers which are tailored to the individual customer demands. This conclusion corresponds to the basic principles of the CRM concept, but it should be mentioned that the personalization of the offer (i.e. the ability to make an individual offer according to the demands of the customer) must correspond to the capabilities and willingness of the respective customer to provide a certain return of the cost of the personalization. Therefore, the personalization can be efficient only under the condition that the customer can directly or indirectly provide certain benefits for the supplier which cover and 
exceed the costs for the personalization of the offer.

The second stage of the strategic process of the management of relationships with customer is the creation of a suitable CRM basis (Table 3). The data in Table 3 show that the mean scores for CRM basis are on the positive side of the scale. The highest mean scores are observed with companies specializing in financial services where $91 \%$ of the respondents state that they have a clear vision about their customers which allows them to efficiently manage their relationships with them. The lowest mean score and the highest value of the standard deviation are observed with the law firms where about $31 \%$ disagree that they have the necessary conditions for efficient management of the relationships with the customers.

Table 2: Mean Scores and Variance in Blocks "Guiding Principles" and "Analysis and Assessment of the Customers"

\begin{tabular}{|c|c|c|c|c|c|c|c|c|}
\hline \multirow[b]{3}{*}{ Statements } & \multicolumn{8}{|c|}{ Type of services rendered } \\
\hline & \multicolumn{2}{|c|}{ accounting } & \multicolumn{2}{|c|}{ financial } & \multicolumn{2}{|c|}{ marketing } & \multicolumn{2}{|c|}{ legal } \\
\hline & $\begin{array}{l}\text { Arith- } \\
\text { metic } \\
\text { mean }\end{array}$ & $\begin{array}{l}\text { Coef- } \\
\text { ficient } \\
\text { of } \\
\text { varia- } \\
\text { tion }\end{array}$ & $\begin{array}{l}\text { Arith- } \\
\text { metic } \\
\text { mean }\end{array}$ & $\begin{array}{l}\text { Co- } \\
\text { effi- } \\
\text { cient } \\
\text { of } \\
\text { vari- } \\
\text { ation }\end{array}$ & $\begin{array}{l}\text { Arith- } \\
\text { metic } \\
\text { mean }\end{array}$ & $\begin{array}{l}\text { Co- } \\
\text { effi- } \\
\text { cient } \\
\text { of } \\
\text { vari- } \\
\text { ation }\end{array}$ & $\begin{array}{l}\text { Arith- } \\
\text { metic } \\
\text { mean }\end{array}$ & $\begin{array}{l}\text { Coef- } \\
\text { ficient } \\
\text { of } \\
\text { varia- } \\
\text { tion }\end{array}$ \\
\hline \multicolumn{9}{|l|}{ Guiding principles } \\
\hline $\begin{array}{l}\text { Managers are } \\
\text { convinced that } \\
\text { CRM increases the } \\
\text { profitability of the } \\
\text { company }\end{array}$ & 4,40 & 0,16 & 4,64 & 0,12 & 4,71 & 0,11 & 4,16 & 0,26 \\
\hline $\begin{array}{l}\text { The company has } \\
\text { specific CRM goals }\end{array}$ & 4,27 & 0,20 & 4,59 & 0,14 & 4,54 & 0,15 & 4,18 & 0,25 \\
\hline $\begin{array}{l}\text { The company has a } \\
\text { clear CRM strategy }\end{array}$ & 4,28 & 0,19 & 4,57 & 0,16 & 4,58 & 0,14 & 4,21 & 0,22 \\
\hline $\begin{array}{l}\text { It is acknowledged } \\
\text { within the company } \\
\text { that the custom- } \\
\text { ers have different } \\
\text { statuses (strategic, } \\
\text { insignificant ...) }\end{array}$ & 3,83 & 0,35 & 4,37 & 0,22 & 4,40 & 0,23 & 4,24 & 0,23 \\
\hline $\begin{array}{l}\text { The company treats } \\
\text { its customers differ- } \\
\text { ently depending on } \\
\text { their status }\end{array}$ & 2,89 & 0,50 & 3,48 & 0,42 & 3,24 & 0,46 & 3,20 & 0,45 \\
\hline \multicolumn{9}{|l|}{$\begin{array}{l}\text { Analysis and as- } \\
\text { sessment of the } \\
\text { customers }\end{array}$} \\
\hline $\begin{array}{l}\text { The company real- } \\
\text { izes that it is neces- } \\
\text { sary to analyze and } \\
\text { evaluate its clients }\end{array}$ & 4,16 & 0,24 & 4,47 & 0,16 & 4,33 & 0,21 & 3,68 & 0,34 \\
\hline
\end{tabular}




\begin{tabular}{|l|l|l|l|l|l|l|l|l|}
\hline $\begin{array}{l}\text { The company real- } \\
\text { izes that analysis is } \\
\text { a prerequisite for } \\
\text { identifying of pro- } \\
\text { spective customers }\end{array}$ & 4,03 & 0,27 & 4,51 & 0,18 & 4,36 & 0,22 & 3,60 & 0,36 \\
\hline $\begin{array}{l}\text { The company re- } \\
\text { alizes that analysis } \\
\text { and assessment of } \\
\text { the customers are } \\
\text { indispensable for the } \\
\text { differentiation be- } \\
\text { tween the customers }\end{array}$ & 3,76 & 0,32 & 3,76 & 0,34 & 3,87 & 0,33 & 3,09 & 0,45 \\
\hline $\begin{array}{l}\text { The company real- } \\
\text { izes that the analysis } \\
\text { of customers is a } \\
\text { condition for effec- } \\
\text { tive interaction with } \\
\text { them }\end{array}$ & 4,21 & 0,23 & 4,47 & 0,17 & 4,43 & 0,17 & 3,71 & 0,35 \\
\hline $\begin{array}{l}\text { The company real- } \\
\text { izes that the analysis } \\
\text { of customers is a } \\
\text { condition for of- } \\
\text { fering personalized } \\
\text { offers }\end{array}$ & 4,20 & 0,23 & 4,57 & 0,15 & 4,71 & 0,12 & 3,54 & 0,39 \\
\hline
\end{tabular}

Table 3: Evaluation of the CRM Basis According to Branches

\begin{tabular}{|l|c|c|c|c|}
\hline \multirow{2}{*}{ Indicators } & \multicolumn{4}{|c|}{ Type of services rendered } \\
\cline { 2 - 5 } & Accounting & Financial & Marketing & Legal \\
\hline Arithmetic mean & 4,35 & 4,45 & 4,32 & 3,96 \\
\hline Standard deviation & 0,80 & 0,73 & 0,82 & 1,10 \\
\hline Coefficient of variation & 0,18 & 0,16 & 0,19 & 0,28 \\
\hline
\end{tabular}

Regardless of the higher value of the standard deviation for the law firms, the deviation does not reach the critical value of $50 \%$ for any of the branches, i.e. the variance lies within acceptable limits. The CRM basis is operationalized through four components: corporate culture, organizational structure, customer research activities and database management.

The customer-oriented corporate culture is expressed though the conviction of the employees on different hierarchical levels that the customers are a key factor for the development of the business. This opinion is shared by a significant part of the managers (between $81 \%$ and 93\%) who had taken part in the study (Table 4). The collected information shows that high mean scores are formed, i.e. the respondents agree that the front office staff in their companies (i.e. the staff which communicates with customers directly) is familiar with the goals and the strategies of the companies regarding the management of the relationships. At the same time there is a significant overlapping of the answers in connection with the statement that the surveyed 
companies have clear procedures for the implementation of customeroriented activities as: offering, service, management of claims etc.

The arrangement of trainings of the staff for work with customers is a part of the customer-oriented corporate culture. A significant variance is observed regarding this matter which reaches the critical level of $50 \%$. The data show (and it is perfectly logical if one takes in consideration the specifics of the respective business) that only financial and credit institutions for the most part (87\%) provide training of the staff for work with customers. Such trainings are a fact (but under certain conditions) only for $36 \%$ of the accounting firms, $55 \%$ of the marketing firms and $41 \%$ of the law firms.

The organizational structure is another component of the CRM basis. It refers to providing conditions for smooth functioning of the processes implementing the CRM concept. Three indicators are provided in this study for the assessment of the adaptation degree of the organizational structure for supporting the processes of management of the relationships. The data in Table 4 relating to the organizational structure of the companies in the three branches are widely divergent. At the same time the variation observed for two of the branches (accounting and legal services) is beyond the acceptable level and reaches $57 \%$. It is remarkable that, again, as it was with the previous statements, the sector of the financial services is represented most positively in connection with provided organizational conditions for efficient management of the relationships with customers.

Table 4 Mean scores and variance in blocks: „Corporate culture“ and

„Organizational structure"

\begin{tabular}{|l|c|c|c|c|c|c|c|c|}
\hline \multirow{2}{*}{ Statements } & \multicolumn{7}{|c|}{ Type of services rendered } \\
\cline { 2 - 8 } & \multicolumn{2}{|c|}{ accounting } & \multicolumn{2}{|c|}{ financial } & \multicolumn{2}{c|}{ marketing } & \multicolumn{2}{|c|}{ legal } \\
\cline { 2 - 9 } & $\begin{array}{c}\text { Arith- } \\
\text { metic } \\
\text { mean }\end{array}$ & $\begin{array}{c}\text { Co- } \\
\text { eff- } \\
\text { cient } \\
\text { of } \\
\text { vari- } \\
\text { ation }\end{array}$ & $\begin{array}{c}\text { Arith- } \\
\text { metic } \\
\text { mean }\end{array}$ & $\begin{array}{c}\text { Coeffi- } \\
\text { cient of } \\
\text { varia- } \\
\text { tion }\end{array}$ & $\begin{array}{c}\text { Arith- } \\
\text { metic } \\
\text { mean }\end{array}$ & $\begin{array}{c}\text { Coef- } \\
\text { ficient } \\
\text { of } \\
\text { varia- } \\
\text { tion }\end{array}$ & $\begin{array}{c}\text { Arith- } \\
\text { metic } \\
\text { mean }\end{array}$ & $\begin{array}{c}\text { Coef- } \\
\text { ficient } \\
\text { of } \\
\text { varia- } \\
\text { tion }\end{array}$ \\
\hline Corporate culture & & & & & & & & \\
\hline $\begin{array}{l}\text { The staff at all } \\
\text { levels is convinced } \\
\text { that customers are } \\
\text { a key factor for the } \\
\text { development of the } \\
\text { business }\end{array}$ & 4,50 & 0,19 & 4,60 & 0,16 & 4,40 & 0,17 & 4,32 & 0,19 \\
\hline $\begin{array}{l}\text { The company or- } \\
\text { ganizes trainings } \\
\text { for work with cus- } \\
\text { tomers }\end{array}$ & 2,89 & 0,49 & 4,32 & 0,25 & 3,52 & 0,36 & 2,90 & 0,47 \\
\hline
\end{tabular}

Type of services rendered 


\begin{tabular}{|c|c|c|c|c|c|c|c|c|}
\hline $\begin{array}{l}\text { The staff which } \\
\text { communicates with } \\
\text { customers is famil- } \\
\text { iar with the goals of } \\
\text { the company }\end{array}$ & 4,38 & 0,22 & 4,67 & 0,14 & 4,47 & 0,13 & 4,10 & 0,26 \\
\hline $\begin{array}{l}\text { The staff which } \\
\text { communicates with } \\
\text { customers is famil- } \\
\text { iar with the strategy } \\
\text { of the company }\end{array}$ & 4,33 & 0,21 & 4,64 & 0,14 & 4,32 & 0,19 & 4,03 & 0,27 \\
\hline $\begin{array}{l}\text { The company has } \\
\text { clear procedures for } \\
\text { the implementation } \\
\text { of customer-oriented } \\
\text { activities }\end{array}$ & 4,25 & 0,22 & 4,53 & 0,19 & 4,32 & 0,20 & 4,01 & 0,28 \\
\hline \multicolumn{9}{|c|}{ Organizational structure } \\
\hline $\begin{array}{l}\text { The organizational } \\
\text { structure of the } \\
\text { company allows ef- } \\
\text { ficient management } \\
\text { of the relationships } \\
\text { with the customers }\end{array}$ & 4,15 & 0,23 & 4,41 & 0,18 & 4,16 & 0,20 & 3,76 & 0,29 \\
\hline $\begin{array}{l}\text { The company has a } \\
\text { department or spe- } \\
\text { cialist/s/ in charge } \\
\text { with the task of } \\
\text { researching cus- } \\
\text { tomers }\end{array}$ & 2,50 & 0,57 & 4,03 & 0,29 & 3,67 & 0,38 & 2,32 & 0,55 \\
\hline $\begin{array}{l}\text { The company has a } \\
\text { department or spe- } \\
\text { cialist/s/ in charge } \\
\text { with the task of } \\
\text { preparing offers to } \\
\text { different customers }\end{array}$ & 2,67 & 0,55 & 4,34 & 0,24 & 3,95 & 0,32 & 2,62 & 0,55 \\
\hline
\end{tabular}

For the other three branches lower mean scores are formed, but as a whole the prevailing opinion is that conditions for efficient management of the relationships exist. The difference in the magnitude of the mean scores of the different statements shows that the opinion on the organizational structure of the managers, who have taken part in the study, is theoretical and in many cases it is not based on concrete facts. When asked if there is a department or specialist in charge with the task of researching customers, a significant part of those who answered positively to the first question no longer express the same opinion. A similar migration of the answers is also observed by the comparison between the first and the third statement. The mean scores for presence within the company of a department or specialist in charge with the task of researching customers are much lower compared to the general scores for presence of appropriate organizational structure for the implementation of the CRM concept.

For each of the four studied branches higher mean scores are formed for the presence of a department or specialist/s/ in charge with the task of preparing offers for different customers compared to the 
mean scores for the presence of a department or specialist/s/ in charge with the task of researching the customers. This means that a part of the modifications of the offers is implemented on grounds of information from operative contacts with customers without conducting special research (which is not a negative observation). Another probability is that the offers are modified in the hope that in this way certain effects would be achieved, i.e. the modifications are implemented by the trial-and-error method. The next component in the framework of the CRM basis is related to customer research activities (Table 5). For this component the lowest mean scores are formed within the strategic CRM cycle. The reason for this conclusion is the lack of established practices for systematical research of the customers in different sections in all of the four branches. This is confirmed by the comparison of the mean scores between the different statements according to branches. Usually the score for the statement about the systematic customer research is higher than the mean scores for all other statements except those related to customer satisfaction and loyalty. This leads to the conclusion that a significant part of the companies (between 59\% for accounting services and $80 \%$ for financial services) observe and research their customers on the grounds of specific criteria and make management decisions about how to interact based on them. However, the data show that for a part of the companies the criteria for customer research do not include the following: volume of purchases, contribution of the customer to the profit, frequency of purchases, propensity to give marketing information and propensity to generate ideas for the improvement of the offer.

This conclusion is not valid for the law firms where the information does not seem to be sufficiently reliable. The reason is the high value of the variation coefficient with four (of a total of eight) operationalizing variables for assessment of the commented component of the CRM basis.

The mean scores, related to the activities for the research of customer satisfaction and loyalty, are higher than the summary score for the systematic customer research. This is valid for all branches and conforms the conclusion here above that, even if the companies do

Inquipy 2016/1 not research their customers systematically, the frequent contacts with them allow the formation of a certain opinion on the satisfaction of the customer and his commitment to the company. 
Table 5: Mean scores and variance in blocks: "Customer research activities" and "Database management practices"

\begin{tabular}{|c|c|c|c|c|c|c|c|c|}
\hline \multirow[b]{3}{*}{ Statements } & \multicolumn{8}{|c|}{ Type of services rendered } \\
\hline & \multicolumn{2}{|c|}{ accounting } & \multicolumn{2}{|c|}{ financial } & \multicolumn{2}{|c|}{ marketing } & \multicolumn{2}{|c|}{ legal } \\
\hline & $\begin{array}{l}\text { Arith- } \\
\text { metic } \\
\text { mean }\end{array}$ & $\begin{array}{c}\text { Co- } \\
\text { effi- } \\
\text { cient } \\
\text { of } \\
\text { vari- } \\
\text { ation }\end{array}$ & $\begin{array}{l}\text { Arith- } \\
\text { metic } \\
\text { mean }\end{array}$ & $\begin{array}{c}\text { Co- } \\
\text { effi- } \\
\text { cient } \\
\text { of } \\
\text { vari- } \\
\text { ation }\end{array}$ & $\begin{array}{l}\text { Arith- } \\
\text { metic } \\
\text { mean }\end{array}$ & $\begin{array}{c}\text { Co- } \\
\text { effi- } \\
\text { cient } \\
\text { of } \\
\text { vari- } \\
\text { ation }\end{array}$ & $\begin{array}{l}\text { Arith- } \\
\text { metic } \\
\text { mean }\end{array}$ & $\begin{array}{l}\text { Co- } \\
\text { eff- } \\
\text { cient } \\
\text { of } \\
\text { vari- } \\
\text { ation }\end{array}$ \\
\hline \multicolumn{9}{|c|}{ Customer research activities } \\
\hline $\begin{array}{l}\text { The company system- } \\
\text { atically researches its } \\
\text { customers }\end{array}$ & 3,41 & 0,37 & 4,05 & 0,26 & 3,76 & 0,29 & 2,63 & 0,51 \\
\hline $\begin{array}{l}\text { The company observes } \\
\text { the satisfaction of its } \\
\text { customers }\end{array}$ & 4,12 & 0,23 & 4,23 & 0,23 & 4,48 & 0,15 & 3,78 & 0,29 \\
\hline $\begin{array}{l}\text { The company observes } \\
\text { the loyalty of its cus- } \\
\text { tomers }\end{array}$ & 3,95 & 0,28 & 4,13 & 0,21 & 4,05 & 0,31 & 3,51 & 0,36 \\
\hline $\begin{array}{l}\text { The company assesses } \\
\text { the customers based on } \\
\text { the purchase volume }\end{array}$ & 3,10 & 0,43 & 3,71 & 0,33 & 3,61 & 0,35 & 2,86 & 0,53 \\
\hline $\begin{array}{l}\text { The company assesses } \\
\text { the customers based on } \\
\text { their individual contri- } \\
\text { bution to the profit }\end{array}$ & 3,28 & 0,39 & 3,73 & 0,35 & 3,70 & 0,34 & 3,13 & 0,43 \\
\hline $\begin{array}{l}\text { The company assesses } \\
\text { the customers based on } \\
\text { the purchase frequency }\end{array}$ & 2,92 & 0,43 & 3,32 & 0,40 & 3,63 & 0,35 & 3,18 & 0,38 \\
\hline $\begin{array}{l}\text { The company assesses } \\
\text { the customers based on } \\
\text { their propensity to give } \\
\text { it marketing information }\end{array}$ & 2,55 & 0,45 & 3,03 & 0,43 & 3,11 & 0,35 & 2,51 & 0,50 \\
\hline $\begin{array}{l}\text { The company assesses } \\
\text { the customers based on } \\
\text { their propensity to give } \\
\text { ideas for the improve- } \\
\text { ment of the offer }\end{array}$ & 2,79 & 0,46 & 2,95 & 0,44 & 3,36 & 0,41 & 2,51 & 0,52 \\
\hline \multicolumn{9}{|c|}{ Database management practices } \\
\hline $\begin{array}{l}\text { The company analyses } \\
\text { information that helps it } \\
\text { to manage the relation- } \\
\text { ships with customers }\end{array}$ & 3,93 & 0,29 & 4,47 & 0,18 & 4,37 & 0,18 & 3,57 & 0,35 \\
\hline $\begin{array}{l}\text { The company maintains } \\
\text { databases with infor- } \\
\text { mation about individual } \\
\text { customers }\end{array}$ & 4,19 & 0,28 & 4,48 & 0,19 & 4,40 & 0,23 & 3,73 & 0,39 \\
\hline $\begin{array}{l}\text { The company maintains } \\
\text { databases with infor- } \\
\text { mation about customer } \\
\text { behavior }\end{array}$ & 3,28 & 0,46 & 3,90 & 0,31 & 4,17 & 0,24 & 2,99 & 0,51 \\
\hline $\begin{array}{l}\text { The company has } \\
\text { software which helps } \\
\text { analyzing customers and } \\
\text { preparing offers }\end{array}$ & 2,94 & 0,53 & 4,03 & 0,30 & 3,70 & 0,40 & 2,33 & 0,57 \\
\hline
\end{tabular}


The last component of the CRM basis is the "database management" (Table 5). The distribution of the answers within this block is logical. Almost all of the companies offering financial and marketing services (90\% - 92\%) implement systematization and analysis of data which allows them to manage the relationships with their customers. The part of the accounting and law firms with such practices is significantly lower - between $63 \%$ and $77 \%$ and it is not a case of availability of information databases based on which to systematically conduct research of the customers. Databases with information about customers are available with over $80 \%$ of the companies. Exceptions thereof are again the law firms where the high value of the coefficient of variation does not allow making a valid conclusion.

The availability of databases with information about customers does not mean a priori that it is a good basis for the management of the relationships. The matter is ,what information exactly is contained in the databases and for what might it be useful?". It turns out that a part of the information databases do not include behavioral information as to: frequency and volume of purchases, number of claims etc.). This does not allow taking into account the past behavior of the respective customer in case of large customer bases if personalization of offers is desired. Therefore, one cannot suggest that the offering takes into consideration all important aspects that relate to the future behavior of the customers. An even smaller part of the companies are equipped with specialized software to help them analyze customers and use this as a basis for the offers. The best performance in this regard show the financial companies ( $74 \%$ have such software) and companies offering marketing services (60\% have such software).

\section{CONCLUSION}

For the achievement of the objective formulated in the paper a tool for the assessment of the strategic readiness for CRM process management in companies specializing in marketing services in the $\mathrm{B} 2 \mathrm{~B}$ market in Bulgaria was designed and tested. The strategic readiness to manage the CRM process is a result from the implementation of a

Inquipy 2016/1 certain vision and concrete infrastructure for the management of the relationships with the customers.

The analysis shows that as a whole the companies specializing in financial and marketing services have a higher degree of strategic readiness for efficient management of the CRM process. This is confirmed by the scores of the different components of the CRM vision and the CRM basis, although initially there is a strong positive opinion of the manager from all branches on the presence of a clear vision on how to interact with customers. The discrepancy in the "Guiding principles" block is somewhat surprising. On the one hand it is stated that the relationships should be managed and that there are clear objectives and strategies according to customers, but on the other hand 
the idea that the customers have different statuses is not accepted. A main idea of the CRM concept is that the personalization of the offers is possible only provided that the customer base is differentiated.

In terms of positive thinking the conclusion can be made that according to the managers who took part in the study the efficiency of the interaction is determined by the ability of the companies to make offers tailored to the individual customer demands. At the same time a high degree of variances of the answers regarding activities for trainings of the staff for work with customers is observed. The most critical result observed is the lack of an established practice of systematic research of customers in different sections.

The main conclusion which arises from the conducted analysis is that businesses with a higher degree of competitive pressure and higher intensity of transfer and replication of leading international practices (financial and marketing services) invest more efforts and resources for the implementation of the principles for management of the relationships with customers which makes them more suitable for successful implementation of CRM projects.

\section{REFERENCES}

Gudkova S., (2005). CRM! Pochemu vnedrenie, a ne "korobka"? Zhurnal "Bankovskoe obozrenie”, N3, (source: http://www.cmdsoft.ru/about/pressa/007/; last access $-20.09 .2015)$.

Alsmadi, S., Alnawas, I., (2001). Empirical Investigation of the CRM Concept in the $I$ Jordanian Context: The Case of Banks and Financial Institutions. International Journal of Business and Management, Vol. 6, N 2, February, p. 183.

Barone et.al., (2000). The Influence of Cause-Related Marketing on Consumer Choice: Does One Good Turn Deserve Another? Journal of the Academy of Marketing Science, 28, Spring, pp. 248-262.

Day, G., (2003). Creating a Superior Customer-Reating Capability. Sloan Management Review, Vol. 44, N 3, pp. 77-83.

Erffmeyer, C., Johnson, D., (2001). An Exploratory Study of Sales Force Automation Practices: Expectations and Realities. Journal of Professional Selling \& Sales Management. Vol. 21, N 2, p. 167.

Johnson, J., (2004). Making CRM Technology Work. British Journal of Administrative Management, Vol. 39, N 3, pp. 22-23.

Kim, H. et al., (2000). Integration of Firm's Resource and Capability to Implement En terprise CRM: A Case Study of a Retail Bank in Korea. Decision Support Sys tems, Vol. 48, N 2, pp. 313-322.

Kinikin, E., (2000). Top 10 CRM Success Factors: Doing It Right. IdeaByte, August, p. 2.

Lamparello, D., (2000). Doing More for the Right Customers. Bank Systems and Tech nology, Vol. 37, N 1, pp. 10-11.

Mack, O., Mayo, M., Khare. A. (2005). A Strategic Approach for Successful CRM: A European Perspective. Problems and Perspectives in Management, 2, p. 100.

Nelson, S., (2002). CRM: From "Nice to Have" to Necessity. Gartner Group, August 2002 (source: q3h3vwb.tripod.com/msce630.../assignment.html; last access - 18.12.2015). 